Acta vet. scand. $1959,1,41-51$.

From the Department of Anatomy, Veterinary College, Helsinki.

\title{
INVESTIGATIONS ON \\ THE PURKINJE CELLS IN THE CEREBELLUM \\ OF SOME DOMESTIC ANIMALS
}

By

S. Talanti.

The Purkinje cells, situated between the outer molecular layer and the inner granular layer in the cerebellum, are large, usually pyriform nerve cells. The structure of these cells has been investigated by various workers. The specific function of the Purkinje cells is unknown. It is impossible to investigate the cells, which are distributed throughout the cerebellum, by revealing them without revealing the whole cerebellum. The cells obviously participate in the typical functions of the cerebellum: the control of equilibrium, the inhibition on the postural reflexes and the reception of the impulses from the entire proprioceptive field (Dukes 1943).

Investigations concerning the structure and histochemistry of the Purkinje cells have been carried out by using various staining methods. The activity of various enzymes is relatively great in these cells. A positive response to a variety of histochemical techniques has been observed (Bourne 1956). This fact has been taken to support the view that intense metabolic processes take place in the cells, which, on the other hand, suggests possible secretory function. Other observations justifying the assumption of secretion have been presented previously. Senise (1935) based his hypothesis mainly on clinic observations. When Bargmann (1949) presented his modification of Gomori's chrome-hematoxylin-phloxine-method for the demonstration of neurosecretion in the hypothalamic-hypophysial system, he opened an extensive field for investigations. Later on it was observed that other staining methods are also applicable to the demonstration of 
neurosecretion in the hypothalamic-hypophysial system e. g. Gomori's aldehyde-fuchsin method. The opinion that secretion obviously takes place in the ganglion cells of the hypothalamus, is largely due to investigations made with these methods. Investigations concerning other parts of the central nervous system have also been carried out with these methods. The Purkinje cells have also been studied with the chrome-hematoxylin-phloxine method. Mosinger (1951) obtained results which may support the opinion of secretion. Thomas (1951) obtained similar results. As far as the present writer knows, no studies of the Purkinje cells made with the aldehyde-fuchsin method have hitherto been published.

The purpose of this study was to investigate the Purkinje cells of some domestic animals mainly with the aldehyde-fuchsin method. Methods for elucidate the structure and nature of the cells as well as purely histochemical methods were used simultaneously.

\section{MATERIAL AND METHODS}

The material consists of the cerebellum of cattle, horses, pigs, sheep, dogs, and cats. As soon as the animals were killed, the brains, avoiding postmortem injuries as much as possible, were removed from the sculls. Applicable pieces of the cerebellum were studied fresh or fixed in suitable solutions. The sections of each cerebellum were made vertically, transversally, and horizontally.

The morphology of the Purkinje cells was studied with Davenport's silver staining method (1930). The tissue was fixed in 10 per cent neutral formalin for 72 hours, and embedded before cutting. The sections were cut at 5 to 10 micra.

The Nissl substance was stained with Einarsson's gallocyanin method (1932) after fixation in 96 per cent alcohol, and paraffin embedding. The sections were cut at 5 to 20 micra, deparaffinized, and dehydrated through xylene and alcohol series. The length of a staining period was 18 hours.

Material treated with Gomori's aldehyde-fuchsin-method was fixed in Bouin's fluid or 10 per cent formalin. Most of the material was embedded in paraffin and cut at 5 to 20 micra. Some sections were made of fixed and frozen material with a freezing microtome. The staining was performed following a modification of the original method (Landing et al. 1956). 
The protein bound sulphhydryl groups were stained with Bennett's method (1951). The tissue was fixed in 10 per cent formalin according to Gomori's recommendation (1956), and embedded in paraffin. The sections were cut at 5 to 20 micra, deparaffinized, and hydrazed, as usual, through xylene and alcohol series. The length of a staining period was at least 18 hours.

The periodic acid Schiff reaction was performed with McManus's method (1946). Material was fixed in 10 per cent formalin and embedded in paraffin. The sections were cut at 5 to 15 micra. Some sections were immersed in saliva for one hour after deparaffinization and hydration. Other sections were immersed in a solution of chloroform and methylalcohol in equal parts at $58^{\circ} \mathrm{C}$ for 24 hours before staining.

Material for the study of alkaline phosphatase was fixed in 70 per cent alcohol and embedded in paraffin. The sections were cut at 10 to 20 micra. The reaction was performed with Gomori's technique (1949).

The fresh frozen material was used for the study of acid phosphatase. After the sections were cut, they were fixed in 4 per cent formalin for a while, usually for only a few minutes. The procedure was made according to Gomori's method (1950).

\section{RESULTS}

With few exceptions the observations regarding the Purkinje cells were identical in all the species investigated.

It was possible to re-examine previous observations on the structure of the Purkinje cells with Einarsson's and Davenport's method. Nissl substance was in general rich in amount and distributed somewhat evenly throughout the cytoplasm. It did not favour any particular part of the cell. The fibrillary network around the cell bodies demonstrated with the silver staining method was very prominent.

Aldehyde-fuchsin positive substance was to be found both in the cytoplasm of the Purkinje cells and their neighbourhood outside the cell bodies (Fig. 1-4). Material occurred as a rule in small granules. Occasionally, the granules were in small aggregations. Cytoplasmic granules were usually present in the periferic zone and only in some parts of the cytoplasm. The material outside the cell bodies was located in the fibrillary network around the cells demonstrable with the silver staining 


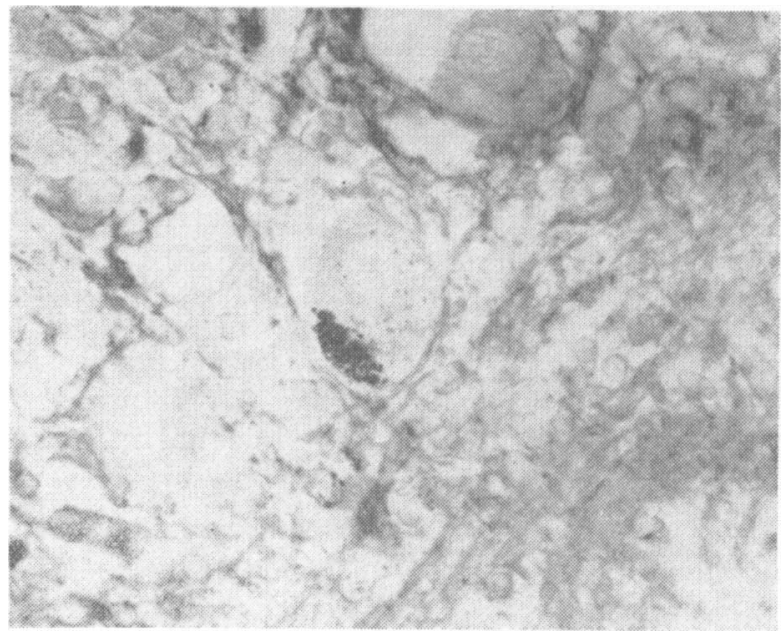

Fig. 1. Purkinje cell from the cerebellum of the dog, showing granules stained with the aldehyde-fuchsin staining. (Magn. $400 \times$ ).

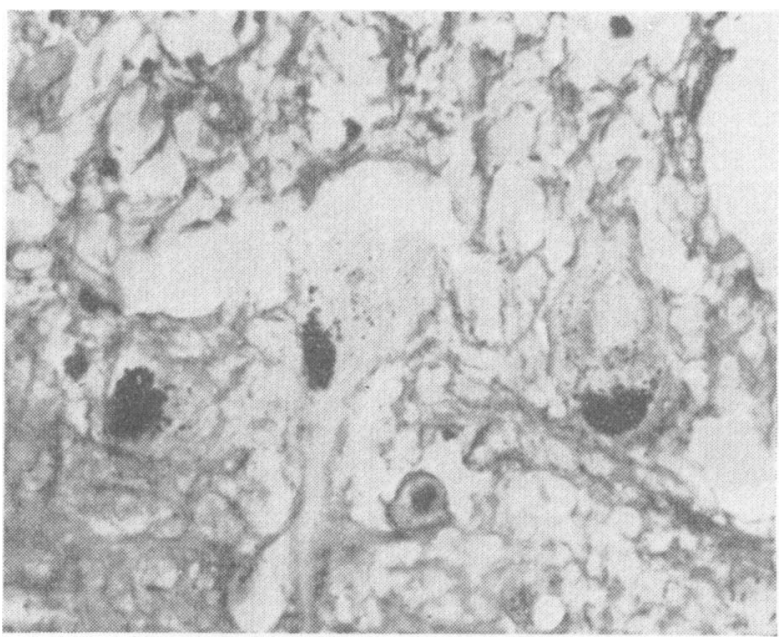

F i g. 2. Group of the Purkinje cells of the horse. Aldehyde-fuchsin positive granules in the cytoplasm. (Magn. $400 \times$ ). 


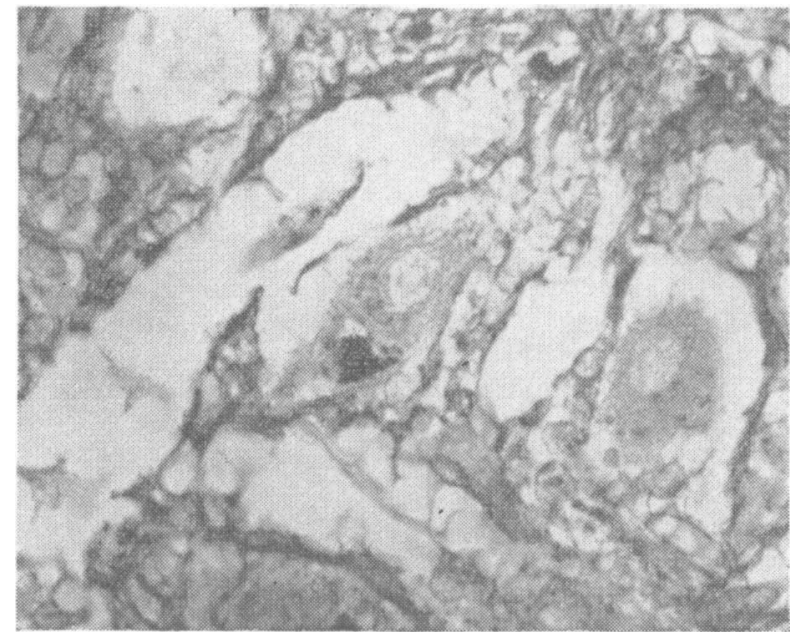

F i g. 3. Purkinje cell of the cow. Aldehyde-fuchsin staining. (Magn. $400 \times$ ).

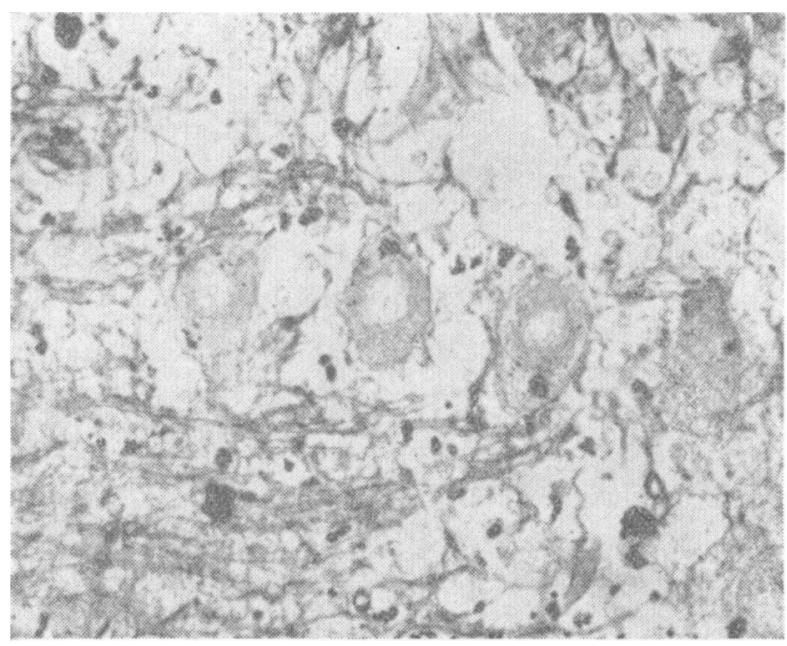

F i g. 4. Group of the Purkinje cells from the dog, showing aldehydefuchsin positive granules also outside the cell bodies. Aldehyde-fuchsin staining. (Magn. $300 \times)$. 


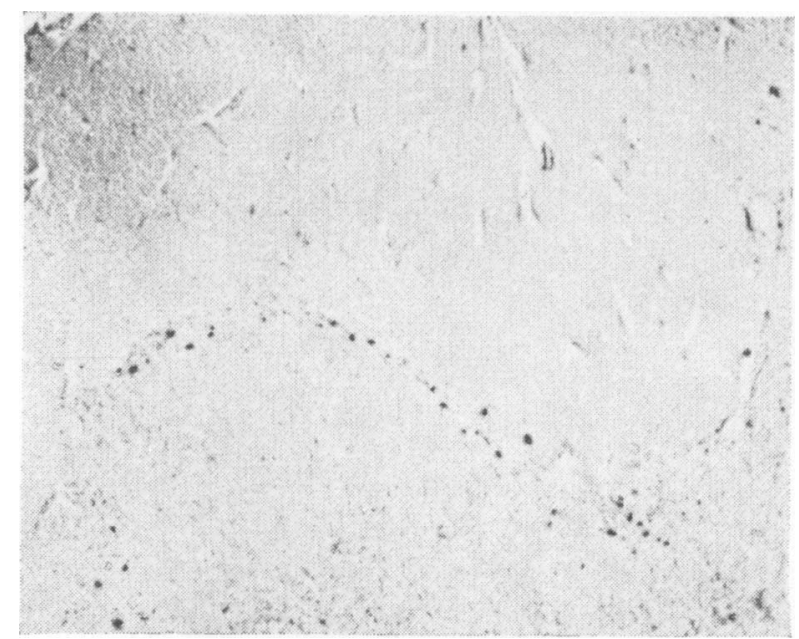

Fig. 5. Aldehyde-fuchsin positive material in an intermediate zone between the molecular and granular layer of the cerebellum of the dog. $($ Magn. $180 \times)$ ).

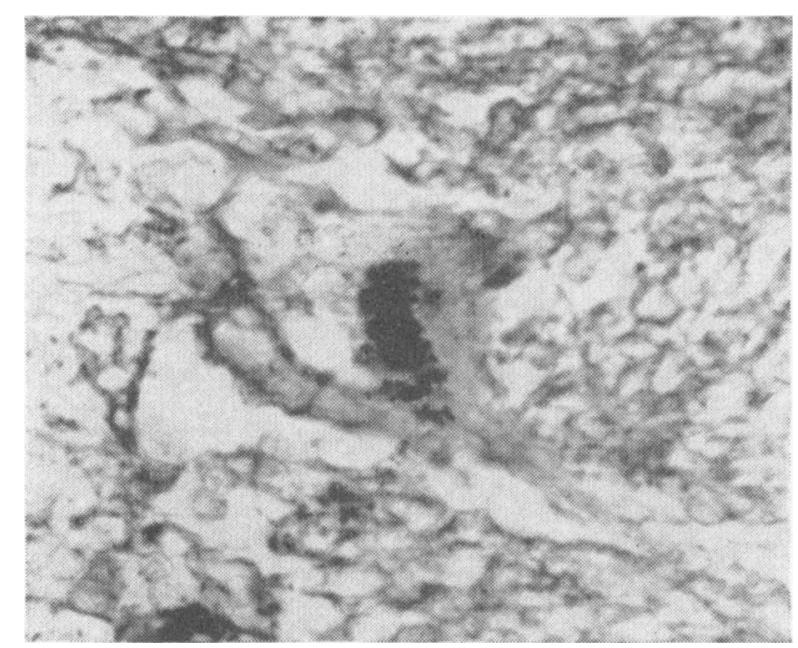

F i g. 6. Purkinje cell from the cerebellum of the horse. Periodic acidSchiff technique. (Magn. $500 \times$ ). 
method. When examining the sections by means of a lower magnification, all the aldehyde-fuchsin positive substance occurred in a narrow intermediate zone between the molecular and granular layer of the cerebellum (Fig. 5). Material was also seen around the blood vessels, but no particular tendency to accumulate could not be observed here. The amount of the material in various species varied slightly, but the differencies were generally small; on the other hand the aldehyde-fuchsin positive material in different cells of the same species varied considerably.

The material also consisting of granules stainable with the periodic acid-Schiff method occurred both in the cytoplasm of the Purkinje cells and outside them in the region of the fibrillary network (Fig. 6). The localization seemed to be the same as that of the aldehyde-fuchsin positive substance. In sections treated with saliva or a mixture of chloroform and methanol differencies in amount or distribution could not be observed.

The sections stained with Bennett's sulphhydryl reagent revealed an orange colour in the cytoplasm indicating a concentration of sulphhydryls. The colour was distributed evenly over the entire cotyplasm.

Both acid and alkaline phosphatase reaction was clear in the Purkinje cells. Activity of acid phosphatase was particularly strong. When comparing the different cells of a section with each other the intensity of the reaction varied, however, though only sligthly.

\section{DISCUSSION}

The results obtained show a distinct acid and alkaline phosphatase activity which is in accordance with the results obtained earlier with the Purkinje cells of various species (Bourne 1956). The acid phosphatase reaction was particularly prominent. $L a$ Velle et al. (1954) observed that the distribution of acid phosphatase activity is similar to that of Nissl substance. The same is the case also with the Purkinje cells of domestic animals in this material. Except for the sites rich in aldehyde-fuchsin positive granules, both the Nissl substance and acid phosphatase activity were distributed fairly evenly throughout the region of the cytoplasm. The abovementioned authors suggested that in nerve cells acid phosphatase may be a part of an enzyme system acting upon a ribonucleoprotein reserve represented by Nissl 
substance to release phosphate for metabolic processes in cell maintenance and function. It is also assumed that nucleic acids are connected with the protein synthesis of the nerve cells, further, that acid phosphatase is necessary for this process. This association is, however, highly speculative. So far as acid phosphatase may be associated with the protein synthesis in the ganglion cells its strong localization in the Purkinje cells somewhat speaks in favour of the secretory function of these cells.

Investigations made with various species show that the neurosecretory ganglion cells in the hypothalamus are generally rich in strongly stainable aldehyde-fuchsin positive material (Dawson 1953, Kivalo \& Talanti 1957). The amount of granules in the Purkinje cells is relatively smaller and demonstrable only in a part of the cytoplasm. According to Sloper (1955), aldehydefuchsin positive material occurred in the ganglion cells e.g. in the nuclei of the third cranial nerve. Similar granules were also stained with the chrome-hematoxylin technique, but the staining was less intense. Sloper states that the exact identity of these granules has not been determined, and they are not necessarily homogeneous. The chemical nature of aldehyde-fuchsin positive material is undecided; for the stain is not spesific but selective. Most investigators do not consider stainable material homogeneous at all. This opinion is supported by the fact that stainable material occurs in different kinds of tissues (Halmi \& Davies 1953, Scott \& Clayton 1953). In the central nervous system it is found most in the hypothalamic-hypophysial system, where its distribution is similar to that of Gomori substance. Aldehyde-fuchsin positive material is also demonstrable in some paraventricular structures e.g. in the subcommissural organ (Wislocki \& Leduc 1954). It is generally believed that the material of these cells consists of the secretion of the nerve cells, while the material in the hypothalamic-hypophysial system is regarded to be the principles of the posterior lobe or their carrier substance (Bargmann 1957). This view is based on parallel physiologic investigations, according to which the localization of hormonal activity for these principles is the same as that of neurosecretory material (Hild \& Zetler 1952). As far as the present writer is aware no corresponding investigations have been conducted concerning the rest of the central nervous system.

Both material demonstrable with the periodic acid-Schiff technique and aldehyde-fuchsin positive material seemed to 
appear in the cytoplasm and outside the cells. The periodic acidSchiff method is believed to indicate the presence of polysaccharides and glycoproteins. Because the sections were treated in an aqueous solution, the material soluble in water did not give the reaction. The amount and distribution of material in the sections treated with a mixture of metanol and chloroform did not vary, either, for which reason the reaction given by certain lipids is not, probably, noteworthy. The treatment with saliva released eventual polysaccharides by turning them into a soluble form. It seems to be obvious that carbohydrate protein complex is present (Leblond 1950). Herbertson \& Dixon (1950) have observed a granular material stainable by the periodic acid-Schiff technique in the Purkinje cells of some species. This material apparently corresponds to the periodic acid-Schiff positive substance in the present material. According to their conclusions this granular material, at least in human neurones, is evidently associated with the so-called lipofuscin or wear-and-tear pigment, and contains a glykolipid.

Bennett's method used in this investigation is suitable for the histochemical demonstration of sulphhydryls, with limitations regarding the specifity of $\mathrm{RSR}$ for the demonstration of -SH groups (Cannefax \& Freedman 1955). The biological importance of sulphhydryl groups in cells has been studied by various workers. These studies are comprehensively reviewed by Barron (1950). In the hypothalamic secretory ganglion cells the positive reaction occurs especially in the area of Herring-substance indicating that this substance is rich in sulphhydryl groups (Sloper 1955). In the cytoplasm of the Purkinje cells, a diffuse positive reaction could be observed. Neither aldehyde-fuchsin positive material nor periodic acid-Schiff positive substance reacts more intensely than the regions close to them. It can be assumed that the activity is due to the sulphhydryl groups bound to the enzyme protein which is essential for the activity of a large number of enzymes.

\section{REFERENCES}

Bargmann, W.: Colston Papers 1957, 8, 11.

Bargmann, W.: Z. Zellforsch. 1949, 34, 610.

Barron, E. S. G.: Advanc. Enzymol. 1951, 11, 201.

Bennett, H. S.: Anat. Rec. 1951, 110, 231.

Bourne, G. H.: J. Anat. (London) 1956, 90, 576.

Cannefax, G. R. \& Freedman, L. D.: Proc. Soc. exp. Biol. 1955, 89, 337. 
Davenport, N.: Arch. Neur. Psych. 1930, 24, 690.

Dawson, A. B.: Anat. Rec. 1953, 115, 63.

Dixon, K. C. \& Herbertson, B. M.: J. Path. Bact. 1950, 62, 335.

Dukes, H. H.: The Physiology of Domestic Animals. 1943, Ithaca, New York.

Einarson, L.: Amer. J. Path. 1932, 8, 295.

Gomori, G.: Quart. J. micr. Sci. 1956, 97, 1.

Gomori, G.: Proc. Soc. exper. Biol. Med. 1949, 70, 7.

Gomori, G.: Stain Technol, 1950, 25, 81.

Halmi, N. \& Davies, J.: J. Histochem. Cytochem. 1953, 1, 447.

Hild, W. \& Zetler, G.: Dtsch. Z. Nervenheilk. 1952, 167, 205.

Kivalo, E. \& Talanti, S.: Acta endocrinol. 1957, 26, 128.

Landing, B., Hall, H. \& West, C.: Lab. Investigation 1956, 5, 256.

La Velle, A., Liu, C. N. \& La Velle, F. W.: Anat. Rec. 1954, 119, 305.

Leblond, C. B.: Amer. J. Anat. 1950, 86, 1.

Mc Manus, J. F. A.: Nature 1946, 158, 202.

Mosinger, M.: C. R. Acad. Sci, Paris 1951, 233, 982.

Scott, H. R. \& Clayton, B. P.: J. Histochem. Cytochem. 1953, 1, 336.

Senise, T.: Cervello 1935, 14, 348.

Sloper, J. C.: J. Anat. (London) 1955, 89, 301.

Thomas, O. L.: J. comp. Neurol. 1951, 95, 73.

Wislocki, G. B. \& Leduc, H. E.: J. comp. Neurol. 1954, 101, 283.

\section{SUMMARY}

The Purkinje cells in the cerebellum of some domestic animals were investigated by using various staining methods, especially the aldehyde-fuchsin method. The cells were rich in acid and alkaline phosphatase. Moreover, the cells contained protein bound sulphhydryl groups. Granular material strongly stainable with the aldehydefuchsin method was discernible. The localization of this material seemed to be identical with the material reacting positively to the acid-Schiff method. The nature of aldehyde-fuchsin positive material and its probable association with neurosecretion were discussed.

\section{ZUSAMMENFASSUNG \\ Untersuchungen über die Purkinje-Zellen im Cerebellum einiger Haustiere.}

Die sog. Purkinje-Zellen wurden bei einigen Haustierarten mit verschiedenen histologischen Methoden, speziell mit der Aldehydfuchsin-Färbung untersucht. In den Zellen wurde eine Aktivität saurer und alkalischer Phosphatase ermittelt. Ausserdem enthielten die Zellen proteingebundene SH-Gruppen und granuläres Material, das kräftig aldehydfuchsin-positiv war. Die Lokalisation des letztgenannten Materials war offenbar identisch mit der Lokalisation PAS-positiven Materials, das sich ebenfalls in den Zellen vorfand. Der Charakter des aldehydfuchsin-positiven Materials und dessen Relation zum neurosekretorischen Material im hypotalamisch-hypophysealen System werden diskutiert. 


\section{SAMMANFATTNING}

Undersökningar av Purkinje-cellerna i cerebellum hos några husdjursarter.

De s.k. Purkinje-cellerna hos några husdjursarter voro undersökta med olika histologiska metoder speciellt med aldehydfuksin-färgning. I cellerna påvisades en aktivitet av sur och alkalisk fosfatas. Dessutom innehöll cellerna proteinbundna SH-grupper och granulärt material, som var kraftigt aldehydfuksin-positivt. Lokalisationen av det sistnämnda materialet var synbarligen identisk med lokalisationen av PAS-positivt material, som även fanns i cellerna. Karaktären av aldehydfuksin-positivt material och dess relation till det neurosekretoriska materialet $\mathrm{i}$ det hypotalamiska-hypofysiala systemet var diskuterad.

(Received June 7. 1958). 